\title{
Súčasná postmoderná rodina a vnútrorodinná del'ba práce
}

\author{
Eleonóra Mendelová
}

\begin{abstract}
Abstrakt: $\vee$ súlade so zmenou spoločenských podmienok aj rodina, resp. život $\mathrm{v}$ rodine prechádza vlastným vývojom, $v$ dôsledku čoho sa tradičná rodina postupne zmenila na rodinu modernú, až na súčasnú rodinu, ktorá sa často označuje prívlastkom postmoderná. Charakteristiky súčasnej postmodernej rodiny, ktoré uvádzame v príspevku, slúžia ako východisko pre analýzu súčasného stavu vnútrorodinnej del'by práce. Naším zámerom je poukázat' na participáciu mužov a žien na každodenných prácach $v$ domácnosti a na starostlivosti o deti, na základe empirických zistení (s akcentom na výskumy $v$ SR a ČR). Ciel'om je tiež analyzovat' názory a očakávania l'udí v oblasti rodičovských rolí a dostat' odpoved' na otázku, či v súčasných rodinách existujú vyrovnané partnerské vztahy $v$ domácnosti, alebo ide o pokračovanie $v$ rodovo špecifickej del'be práce $v$ domácnosti.
\end{abstract}

Kl'účové slová: postmoderná rodina, del'ba práce, matka, otec, domáce práce, starostlivost' o deti, rodičovské roly

\section{1 ÚVOD}

Rodinu považujeme za sociálny útvar, sociálnu skupinu, ktorá logicky prechádza vlastným vývojom, a to $v$ súlade so zmenou spoločenských podmienok. Rodina vo svojom pôsobení priamo i nepriamo reflektuje stav a možnosti spoločnosti, no pritom zo všetkých sociálnych inštitúcií najmenej podlieha priamemu riadeniu spoločnosti.

Radikálna kritika rodiny skutočne preukázala, že inštitúcia, ktorá bola považovaná za snád'najstabilnejší výtvor našej civilizácie, sa najmenej od konca prvej svetovej vojny podstatne zmenila a d'alej sa mení. Mení sa nie marginálne, ale vo svojich najzákladnejších charakteristikách. Zmeny sú pozorovatelné v posledných desatročiach, väčšinou majú svoje impulzy na rozhraní 19. a 20. storočia, s akceleráciou po druhej svetovej vojne (Plaňava, 2000). Podobný názor prezentuje Možný (2006), podla ktorého sa jedná o zmeny s hlbokými koreňmi, ale práve $v$ druhej polovici 20. storočia sa zviditel'nili (napr. rodina stratila monopol na legitímny sex, výber partnera už nie je v rukách rodičov, slabne transcendentálna garancia manželského zväzku, rodina stratila niektoré tradičné funkcie, vytvorili sa nové typy rodín, prejavila sa väčšia pracovná angažovanost' žien mimo rodiny, zmenili sa mužské a ženské roly...). To všetko sú podstatné zmeny, ktoré zasahujú do sociálnej štruktúry súčasných spoločností nášho civilizačného okruhu i do individuálnych životov ich členov.

\section{ZMENY RODINY}

Podla Možného $(2002,21)$ otrasenie konceptu rodiny ako morfostatickej inštitúcie je odvodené zo situácie, kedy rodičia boli záväzným a viac-menej jediným vzorom pre nastupujúce generácie a nazhromaždená skúsenost' sa predávala pomalou socializáciou z rodičov na diet́a. $V$ kontexte so zmenami rodiny máme tendenciu odvodzovat' zmeny od obrazu tzv. „tradičnej rodiny“. 
Predstava „tradičnej rodiny“ vyzerá ako obdivuhodne homogénna, vyznačujúca sa formami rodinného života, $v$ ktorej sú obaja rodičia detí manželmi, žijúcimi so svojimi det'mi v spoločnej domácnosti. Roly $\checkmark$ takejto rodine podla vžitej predstavy sú rodovo špecificky rozdelené, otec v rodine spravidla vykonáva zamestnanie mimo rodiny, spojené s dochádzkou do zamestnania, do práce. Matka sa stará o výchovu detí a o domácnost'. Deti navštevujú školu a pripravujú sa na svoje budúce povolanie. Tento spôsob života nie je poznačený konfliktmi, každý prijíma $v$ rodine svoju rolu, čo je základom prevládajúcej harmónie $v$ rodine. Skutočnost' je však taká, že uvedený model rodiny bol už od konca 60 . a začiatku 70. rokov skôr výnimkou (Ondrejkovič - Majerčíková, 2006, 10).

Zmenil sa tiež model monogamnej, neolokálnej a dvojgeneračnej rodiny. Ako uvádza Možný $(2002,22)$ aj ked' bol tento model od polovice 20. storočia normatívne záväzný a ako normatívny model ostáva pre väčšinu populácie v platnosti, nemôžeme prehliadat jeho varianty a odchýlky, od rôznych foriem nemanželského spolužitia cez programovaný život mimo rodinné zväzky, či manželstvo až po spolužitie homosexuálov a adoptívne rodiny lesbičiek.

Vývoj rodiny nadobúda stále väčšiu dynamiku, je stále viac poznamenaný zásahmi zvonku. Retrospektívny pohl'ad na rodinu $v$ Európe $v$ priebehu posledných desatročí odhaluje vo vývoji rodinných vztáahov a štruktúr tieto základné procesy (Guráň et al., 1997, 5-6):

- Demokratizácia rodinných vztáahov, t. j. pozvol'ná premena tradičných, patriarchálnych rodinných vzt́ahov, založených na autorite muža a podriadenosti detí rodičom, na vztahy moderné, rovnoprávne $z$ hl'adiska pohlavného, ako aj generačného.

- Individualizácia rodinných vztáahov, t. j. postupný prechod od vztahov daných, prioritne určených pôvodom človeka ku vztahom prevažne voleným, utváraným slobodným výberom jednotlivca, založených na vzájomnej diskusii;

- Dynamizácia rodiny, t.j. rodina sa stáva viac otvorenou, prístupnejšou, adaptabilnejšou na zmeny, ktoré vývoj spoločnosti prináša, ale aj na zmeny v individuálnom vývoji človeka;

- Pluralizácia rodinných štruktúr a foriem, t. j. rodina nadväzuje na predchádzajúce procesy a utvára stále širšiu a komplikovanejšiu paletu rodinných vztahov, formuje sa väčší počet rodinných štruktúr (z ktorých mnohé boli predtým ojedinelé), riadiacich sa novými, vlastnými vzormi správania.

Môžeme konštatovat', že sociálna inštitúcia rodiny prechádza v súčasnej individualizovanej spoločnosti zmenami: mení svoju formu a štruktúru, naberá nové funkcie, menia sa demografické procesy, oblast' rodičovských rolí, rodinných vztahov atd'. Súčasná rodina je v sociologickej literatúre často označovaná prívlastkom postmoderná. Ako prvý identifikoval postmodernú rodinu Shorter (1975, In Možný, 2006), ktorý ju charakterizoval tromi znakmi: 1 . hodnotová diskontinuita medzi rodičmi a det́mi, vyplývajúca z väčšej hodnotovej závislosti detí od masmédií než od rodičov; 2. nestabilita v párovom živote, odrážajúca sa v náraste rozvodovosti a nemanželského spolužitia; 3 . systematická demolácia konceptu „rodinného hniezda“ nukleárnej rodiny v novej liberalizácii žien. Uvedené charakteristiky súčasnej rodiny však môžeme doplnit' o jej d'alšie znaky.

Ked'že prioritne je predmetom nášho záujmu slovenská, resp. česká rodina, vychádzajúc z prác slovenských a českých autorov (Možný, 2002, 2006; Plaňava, 2000; Rabušic, 2001; Střelec, 2007; Tamášová, 2007; Výrost, Slaměník, 2001 a d’alší) sa nám javia ako charakteristiky súčasnej rodiny nasledovné znaky:

- Základná rodina stráca svoju ritualizovanú podobu. Legalizácia partnerského spolužitia $v$ súčasnosti nie je podmienkou rodinného života a narastá podiel rodín založených na spolužití partnerov bez uzavretia manželstva. Charakteristická je vysoká spoločenská tolerancia voči novým formám spolužitia;

- Diskontinuita generácií a zmena štruktúry rodiny. Klesá nielen počet detí v rodine, ale obmedzuje sa tiež viacgeneračné spolužitie a narastá počet osôb žijúcich v jednočlenných domácnostiach; 
- Pokles stability rodiny. $\mathrm{V}$ posledných desat'ročiach z dôvodov objektívnych (emancipačný proces, nárast ateizmu) alebo subjektívnych (manželstvo je zakladané na emotívnej báze), dochádza k nárastu rozvodovosti. Väčšina rozvádzajúcich sa manželstiev má deti. V dôsledku toho narastá počet detí žijúcich $v$ jednorodičovských rodinách;

- Rozvoj zaznamenáva antikoncepcia a plánované rodičovstvo. Ubúda "nechcených“ tehotenstiev, pričom postoje $\mathrm{k}$ umelému prerušeniu tehotenstva sú značne liberálne. Rast významu a dostupnosti antikoncepcie pri plánovaní rodičovstva spôsobujú v konečnom dôsledku zníženú pôrodnost';

- Zmeny v organizácii rodinného cyklu. Rodičmi sa stávajú osoby vo vyššom veku, deti sa začínajú rodit' až po uplynutí určitého času manželstva či partnerského spolužitia. Starými rodičmi sa stávajú stále staršie osoby, ktoré sú však často zapojené do pracovného procesu;

- Dvojkariérové manželstvá. Rast vzdelanosti a kvalifikovanosti, a tým aj zamestnanosti žien spôsobuje, že sa skracuje čas rodičov strávený s det́mi a s ostatnými členmi rodiny. Okrem nedostatku času je problémom spôsob trávenia času, ale aj obmedzené možnosti na bezprostredný kontakt a „spoločný“ život, celkovo vypätý životný štýl, nesúlad medzi pracovnými a rodinnými povinnostami;

- Predlžuje sa dlžka života, a tým aj trvanie rodiny po odchode detí. Dlhšia je tiež doba, počas ktorej žijú deti s rodičmi v jednej domácnosti. Vzrastá tak socializačný dosah mladej generácie na starších príslušníkov rodiny;

- Sekularizácia. Znižil sa vplyv cirkvi na rodinu, presadzuje sa svetský spôsob života a následný ateizmus;

- Vyšší dôraz na materiálne hodnoty. Evidentná je snaha vyrovnat' sa životnou úrovňou iným vyspelým štátom a zabezpečit' si väčšie pohodlie, súkromie a bohatstvo;

- Množstvo funkcií rodiny prevzali iné sociálne inštitúcie - škola prevzala od rodiny vzdelávanie, lekári, nemocnice a siet' sociálnych zariadení prevzali od rodiny starostlivost' o chorých, starých a postihnutých. Mimoriadny význam nadobudli dve funkcie rodiny: prvotná socializácia a emocionálna funkcia.

Súčasná postmoderná rodina je podl'a de Singlyho (1999) charakteristická tým, že ide o rodinu s intímnymi vztahmi, ktorá predstavuje akýsi fungujúci „súkromný priestor" na spolužitie osôb, ktoré spája. Vyčlenila sa v nej vzt́ahová zóna (vzt́ah medzi mužom a ženou - vztáah afinity, vztáah medzi rodičmi a det'mi - vztahah filiácie), preniknutá citovou blízkostou manželov (často ešte v období predmanželskej známosti, rozhodnutím o jej potvrdení manželstvom a počatím dietatáa).

Z historického hladiska teda rodina zaznamenala nemalé zmeny. Vývojovo prešla od rodiny patriarchálnej po rodinu dvojgeneračnú, nukleárnu, od tradičnej po rodinu modernú až postmodernú, od rodiny s pevne stanovenými rolami muža a ženy po rodinu partnerskú. Zmeny sa dotýkali rozsahu a štruktúry rodiny, a tým aj bohatstva vztáahov v rodine, akceptovania alebo opúšt́ania určitého systému rodinných hodnôt, del'by práce a stability sociálnych rolí mužov a žien, otcov a matiek, foriem rodinného spolužitia (Matejček, 1989).

\section{PRÍČINY ZMIEN V RODINE}

Za príčinu zmien v rodine v posledných desat́ročiach sa podla mad'arskej autorky Vajda (In Vajda, Kósa, 2005, 166) často, ale omylom považujú zmenená sexuálna morálka, nárast pracovnej angažovanosti žien či médiá. Podrobnejšia analýza však poukazuje na väčšiu zložitost' skúmaného problému. Za diferenciáciu rôznych foriem spolužitia len sčasti môže nárast osobnej autonómie a rozširujúce sa možnosti vol'by (práca žien, detské zariadenia atd'.). Vzniknutá situácia je niekedy 
očividne nutnost'ou, nie dôsledkom vol'by. Za pričiny premeny rodiny autorka považuje skutočnost', že možnosti jedinca na spoločenskú integráciu sa dostávajú čoraz d’alej od rodiny. Ďalšou príčinou narastajúcej diferenciácie foriem spolužitia je anómia, t. j. nedostatok noriem, čo stáažuje zladenie dôležitých rozhodnutí, životných ciel'ov, či hodnôt partnerov. Dôležitú rolu zohrávajú aj neustále zmeny pracovných a hospodárskych okolností, putovanie medzi krajinami, resp. regiónmi krajín, čo znemožňuje trvalú rodinnú integráciu.

Nemecký sociológ Beck (1992, In Rabušic, 2001, 226) za príčinu zmien, ktoré v súčasnej rodine prebiehajú, považuje protiklad medzi trhom a rodinou. Na vysvetlenie uvádza, že tržný model modernej spoločnosti vo svojich konečných dôsledkoch implikuje spoločnost' bez rodín a detí. Moderný trh predpokladá pružnú mobilitu pracovných síl bez ohladu na osobnú situáciu pracovníkov a v takom prostredí je ideálnym tržným subjektom slobodné indivíduum, neobmedzované vztahom, manželstvom alebo rodinou. Aj ked' vyjadrenia Becka treba brat' $s$ istou rezervou, nemôžeme tento názor opomenút a treba ho považovat' za jeden z mnohých príčin zmien v rodine.

V kontexte vztahu rodiny a trhu Možný $(2006,234)$ poukazuje na neúprosný imperatív trvalého ekonomického rastu, ktorý podmýva hradbu medzi súkromným a verejným. Podla autora nie je možné, aby boli ženy držané mimo verejnú sféru, najmä sféru ekonomického života. Investície, ktoré dnes ženy bežne vkladajú do svojho vzdelania, chýbajúca záruka trvalosti v manželstve, spravidla jedno alebo dve deti narodené $v$ odstupe niekol'ko málo rokov, predlžovanie dlž̌ky života a produktívneho veku, zjednodušenie domáceho hospodárenia, to všetko otvára v ženskom živote kapacity, ku ktorým mali tradične prístup iba muži. Trvalé zvyšovanie životnej úrovne spôsobuje pre rodinu neobyčajne tažké zotrvat' pri modeli rodiny s jedným príjmom.

Zmeny, ktoré so sebou prináša moderná a neskoro moderná spoločnost', sa týkajú predovšetkým ženy (Rabušic, 2001, 224). Tým, že sa žene nesmierne otvorili životné šance, jej prvoradá orientácia na manželstvo a materstvo sa oslabuje. Akonáhle má žena spoločenské, intelektuálne alebo profesionálne ambície a má prostriedky na ich napĺnanie, láka ju menej investovat' čas a energiu do výchovy detí. Kým $\checkmark$ minulosti bola rodina a materstvo pre ženu údelom, dnes sa stali jej vol'bou. Podl'a Možného (1990, 121) v tradičnej spoločnosti práca v domácnosti integrovala ženu do sociálneho systému vyššieho rádu (privádzala ju do „spoločnosti“), kým pre súčasné ženy sa stala domácnost' miestom sociálnej izolácie. Zmenami technológií, životného tempa, typov bývania i rodinných systémov sa stalo, že široká paleta „domácich“ prác, predtým vykonávaných kolektívne (často mimo vlastný dom), bud' zmizla zmenami technológie alebo bola individualizovaná.

Okrem vyššie spomenutých vysvetl'ujúcich príčin sa ako d'alšie príčiny uvádzajú: pokračujúce emancipačné hnutie žien, dostupnost' interrupcií, mení sa tiež hodnotová orientácia v spoločnosti a morálne cítenie, viac sa tolerujú mimomanželské vzt́ahy, dostupnost' antikoncepcie dodáva zdanlivý pocit kontroly situácie, upadá vplyv náboženských kódexov na rodinný život. Oproti predchádzajúcim dobám existujú vyššie očakávania partnerov, aby bol pre nich vztah osobne uspokojivý.

V priebehu niekol'kých generácií sa zásadne zmenili vztahy, ktoré sa v priebehu predchádzajúcich generácií len málo menili. Na prvom mieste je to vztáah muža a ženy, ktorý sa dnes stáva rovnoprávnym v pravom slova zmysle. Ženy sú, v dôsledku rovnakého vzdelania, vplyvu občianskej spoločnosti a sociálneho štátu, voči mužom menej závislé, a to v ekonomickej i rodičovskej role.

Uvedené zmeny, ku ktorým v spoločnosti nášho kultúrneho okruhu dochádza, vyvolávajú okrem iného i záujem a diskusiu o role otca a matky $v$ rodine a zodpovednosti, ktorá sa $k$ nim viaže. $V$ tejto súvislosti je opodstatnené sa pýtat', $\mathrm{k}$ akým faktickým zmenám došlo $v$ usporiadaní genderových rolí $v$ rámci rodiny, najmä aké obsahové a hodnotové zmeny postihli výkon roly otca a matky. 


\section{VNÚTRORODINNÁ DEL'BA PRÁCE}

Rodina, rovnako ako del'ba práce medzi pohlaviami, je dôsledkom istého historického, ekonomického a politického vývoja, a nie biologickou „prirodzenou“ danost'ou. Neexistuje nejaká konštantná podoba rodiny či del'by práce, existujú však alternatívy, ktoré ale môžu priniest' stratu istých výhod a privilégií pre doposial' zvýhodnenú skupinu obyvatel'stva.

Prístupy, ktoré môžeme súhrnne označit' ako socializačné či genderové, zdôrazňujú, že rozdelenie pracovných zodpovedností v rodine ovplyvňujú i významy a hodnoty, aké muži a ženy pripisujú výkonu domácich prác. Vzhladom na to, že starostlivost' o domácnost' je tradične spájaná s gender rolou žien a je sociálne konštruovaná ako ženská práca, odráža del'ba práce $v$ domácnosti a rutinné vykonávanie (alebo nevykonávanie) domácich prác i to, aké predstavy majú muži a ženy o svojich gender rolách a aké sú ich očakávania voči role ich partnera. Postoje k genderovým rolám, t. j. preferencia tradičnej roly muža a ženy, alebo podpora vzájomnej zastupitel'nosti rodinných rolí, môžu posilňovat' (prípadne oslabovat', ak sú s nimi v rozpore) rozhodnutia o rozdelení rolí v rodine, ktoré sú výsledkom ekonomických kalkulácií (Chaloupková, 2005, 61).

Problém domácich prác, ich del'by $v$ rodine a delegovania sa $v$ súčasnosti objavuje predovšetkým $v$ súvislosti s fenoménom „nových” otcov (t. j. otcov ,angažovaných” a aktívnych v rámci rodiny) a s presadzovaním demokracie v súkromnej sfére. Zatial' čo ženy už dávno prenikli do verejnej sféry platenej práce a ich rovnoprávnost' je aspoň oficiálne garantovaná legislatívnymi opatreniami, $v$ prípade mužov nemožno konštatovat' rovnako úspešný prienik do sféry rodinnej. Muži sú síce "angažovanejší v starostlivosti o deti a ich výchovu, táto aktivita má však väčšinou podobu „,hrania" a učenia sa s det'mi. Výsledky výskumov na Slovensku i v Čechách ukazujú, že del'ba práce v domácnosti napriek rastúcej účasti mužov na domácich prácach je stále nerovnomerná.

Rodina a domácnost' je oblastou, v ktorej sa i nad'alej produkuje a reprodukuje „nerovná" del'ba práce, povinností a právomocí podla pohlavia (Maříková, 1999, 23). Oproti minulosti sa však už zdôrazňuje, že neúčast' mužov na domácich prácach (typu žehlenie, pranie, vysávanie a pod.) je záležitostou tak mužov, ako i žien. Na strane mužov sa konštatuje častá neochota zapájat' sa do tzv. ženských prác, na strane žien je nemenej častá nespokojnost' $s$ „nízkym štandardom” mužmi vykonanej práce $v$ domácnosti. V tomto kontexte sú zaujímavé zistenia Holubovej $(2006,97)$, podla ktorých sa chce viac venovat' domácim prácam $33,5 \%$ a starat' sa viac o deti $42,2 \%$ opýtaných mužov. Očakávanie žien sú $v$ tomto smere vždy vyššie a jednoznačnejšie (väčšiu účast' na domácich prácach si praje $42,2 \%$ a väčší podiel na starostlivosti o deti $76 \%$ ).

Podla Bútorovej et al. (2008, 31 - 33) i napriek určitým názorovým posunom ludia na Slovensku ešte vždy očakávajú schopnost́ postarat' sa o domácnost' ovela častejšie od ženy než od muža. Na druhej strane mužovi pripisujú viac autority v rodine. Podla autorky je na Slovensku už pomerne málo l'udí, ktorí sa otvorene hlásia $\mathrm{k}$ predstave, že by väčšina starostlivosti o deti a domácnost́ mala pripadat na ženy. Takýto názor zastáva iba pätina žien ( $21 \%$ ) a necelá tretina mužov $(29 \%)$. Na druhej strane účast' oboch manželov na týchto prácach preferuje 62 \% žien a $52 \%$ mužov. Žena by sa síce mala vediet' postarat' o domácnost', ale to neznamená, že by na to mala byt sama. Z výskumu Maříkovej $(2006,85)$ vyplýva, že matka je stále vel'mi dôležitou osobou v rodine, lebo prevažne na nej spočívajú časovo najpravidelnejšie (t. j. každodenná komunikácia a bazálna starostlivost') a často i časovo najnáročnejšie aktivity (ako starostlivost' v chorobe, pri učení) vo vztahu k dietatúu. Otec sa objavuje spolu s matkou pri tých aktivitách, ktorých pravidelnost́ nie je až taká urgentná (napr. rozhodovanie o štúdiu, povolaní, trestanie detí, nakupovanie darčekov) a záväznost' nie je až taká obligatórna (vol'nočasové aktivity).

Z hladiska každodennej starostlivosti a výchovy detí vychádza podl'a výskumných údajov, podobne ako $v$ minulosti, ako najdôležitejšia matka. Nie je ani jedna oblast' starostlivosti, v ktorej by matka venovala dietatúu menej času ako otec. Napr. podla údajov z výskumu vidieckej rodiny bola účast' 
matky pri učení sa s det́mi $39 \%$ a účast' otcov len $3 \%$. V prípade návštevy lekára bol rozdiel ešte výraznejší: 52 \% ku 4 \%. Jediný druh starostlivosti, u ktorého sa prevaha matiek nepotvrdila, boli hry s det́mi. Túto aktivitu vykonávajú rodičia spoločne (Filadelfiová, 2001; Bodnárová, et al., 2004).

K podobným zisteniam dospela Holubová (2011), podla ktorej participatívny model, t.j. sledované činnosti vykonávané aj otcami, sa vztáahoval iba na vol'nočasové aktivity (prechádzky a hry s det'mi, rozhovory s det'mi o ich radostiach, problémoch). Na ostatných sledovaných činnostiach sa participatívny model presadil iba na úrovni 30 \% (vodenie do škôlky/školy, učenie sa s det́mi, starostlivost' o deti v čase choroby), $v$ prípade každodennej starostlivosti o domácnost' a deti iba na úrovni $20 \%$. Pritom výskumy dokumentujú, že rodinné politiky zasadené v rodovo citlivom sociálnom štáte majú pozitívny vplyv na počet detí v rodine, znižovanie rodových príjmových rozdielov, a tým aj znižovanie rizika finančnej a sociálnej závislosti žien od sociálneho systému. Podpora otcovstva napr. osobitne vyčlenenou otcovskou dovolenkou, zvyšuje mieru participácie mužov na starostlivosti a aktivizuje ich otcovstvo. Aktívne otcovstvo má potom pozitívny vplyv na stabilitu rodiny, počet detí v rodine a znižuje riziko domáceho násilia.

Niekedy sa v súvislosti s týmto fenoménom používa pojem „noví otcovia“. Výskumy dokazujú, že za posledné desat́ročia sa s otcovstvom udiala zmena. Narastá počet otcov pri starostlivosti o dieta. Otcovia trávia viac času so svojimi det́mi ako predchádzajúca generácia otcov a pozdvihla sa emocionálna úroveň vzt́ahu otec - dietáa. Ako uvádza Yablonsky $(1995,23)$ už „, priebehu 80. rokov bolo možné sledovat' ako mnohé prvky citovej výchovy detí už nie sú len materskou záležitost́ou, ale sa stali súčast'ou modernej otcovskej roly“.

Podla autorov Danielsa a Weingartena (1983, In Vajda-Kósa, 2005, 252) až do 70. rokov 20. storočia bola rola otcov vo výchove detí považovaná za okrajovú. Z výskumných údajov vyplýva, že pri porovnaní rodičov, ktorým sa narodili deti v pätdesiatych, šest'desiatych a sedemdesiatych rokoch 20. storočia, otcovia $v$ sedemdesiatych rokoch venovali dvakrát tol'ko času starostlivosti o deti ako otcovia $v$ pätdesiatych a šest'desiatych rokoch. Mnohé výskumy z 80. rokov referujú o tom, že narastá počet otcov, ktorí sú značne zainteresovaní na starostlivosti o deti, hlavne v predškolskom veku. Výskumné údaje pochádzajúce z Vel'kej Británie tiež potvrdzujú vzrastajúcu účast' otcov na starostlivosti o deti (Lewis et al., 1981, In tamtiež). Z výskumu vyplýva, že kým v r. 1960 otcovia ani raz nevstali v noci kvôli svojmu dietatúu a len 30 \% otcov pomáhalo v domácnosti v období po pôrode, tak v r. 198087 \% otcov bolo ochotných prerušit' svoj nočný spánok kvôli dietatúu a 77 \% otcov pomáhalo v domácnosti.

Tradičná vnútrorodinná del'ba práce, osobitne vo veci domácich prác, sa síce postupne mení, ale ženy v rodine zostávajú stále vo väčšej miere „kompetentnejšie“ v domácich prácach ako muži. Podla výskumných zistení Chaloupkovej (2005) ženy venujú domácim prácam týždenne v priemere dvakrát viac času ako muži (23,5 hod. a 11 hod. a 42 min.) a vykonávajú prevažnú čast' domácich činností.

Bežné práce $v$ domácnosti ležia predovšetkým na pleciach žien. Tie vždy alebo prevažne perú a žehlia (podla vyjadrenia 94 \% žien žijúcich s partnerom a 92 \% mužov žijúcich s partnerkou), varia (podl'a $80 \%$ žien a $75 \%$ mužov), upratujú ( $73 \%$, resp. $66 \%$ ) a umývajú riad (72 \%, resp. $67 \%)$. Model, ked' sa ženy a muži o tieto práce delia, sa podl'a výskumu Filadelfiovej (In Bútorová et al., 2008, 235) vyskytuje maximálne $v$ tretine prípadov. Úplne ojedinelé sú domácnosti, kde tieto činnosti vykonávajú muži. Jedinou bežnou prácou, na ktorej sa muži podiel'ajú výraznejšie, je nakupovanie potravín. Celkovo je však participácia mužov na každodenných prácach v domácnosti, ktoré sa v literatúre zvyknú označovat́ ako „špinavé“ domáce práce, nízka. A nie je to preto, že by muži takúto prácu nevedeli robit. Spomedzi mužov bez partnerky vykonáva tieto činnosti vždy alebo prevažne $35 \%$ až $40 \%$, ale spomedzi mužov žijúcich v partnerskom vztahu iba $1 \%$ až $10 \%$. Vstup do partnerstva teda znamená pre mužov výrazný úbytok zodpovednosti za bežné domáce práce a ich úplné alebo čiastočné delegovanie na ženy. Pre väčšinu žien bez ohl'adu na rodinný stav je typické, že tieto činnosti vykonávajú spravidla ony. Podla autorky je však dôležité nielen to, že „oslobodenie“ 
mužov od prevažnej zodpovednosti za bežné práce $v$ domácnosti je na Slovensku každodennou realitou, ale aj to, že to zodpovedá normatívnym predstavám populácie.

Empirická evidencia ukazuje, že napriek určitým zmenám postojov, ked' v spoločnosti slabne presvedčenie o tradičnom usporiadaní genderových rolí platí, že ženy vykonávajú prevažnú čast' práce v domácnosti - i v prípade, že majú platené zamestnanie (Chaloupková, 2005) a podiel otcov na starostlivosti o deti, ako aj na domácich prácach je stále výrazne nižší ako podiel matiek (Maříková, 2006).

Aj ked' zoslabuje výlučne individuálny, resp. separovaný výkon rodičovských rolí u oboch rodičov, matky zostávajú v porovnaní s otcami tými osobami, ktoré stále, i ked'v menšej miere ako kedysi vykonávajú najnáročnejšie časové aktivity a činnosti majúce charakter každodennej starostlivosti. Z tohto môžeme nepriamo vyvodit, že na ženách stále spočíva i omnoho väčší podiel zodpovednosti, než aký fakticky v starostlivosti o deti a pri ich výchove náleží mužom.

Pretože sa muži viac ako predtým zapájajú do výkonu niektorých aktivít, ich zapojenie vzrastá tam, kde nie je vyžadovaná pravidelnost' výkonu, a tiež u tých činností, ktoré nutne nesúvisia so základnou starostlivostou o dieta. Súčasná generácia otcov sa oproti generácii svojich otcov (alebo starých otcov) viac angažuje najmä pri vol'nočasových aktivitách a pri tých aktivitách, ktoré nemusia byt' vykonávané sústavne a pravidelne. Muži sú stále omnoho menej ako ženy rodinou zat́ažovaní a obmedzovaní, a to tak časovo, ako aj mentálne (nie sú zatažovaní pravidelnostou a naliehavost́ou opatrovatel'ských a výchovných povinností). Muži sa najväčšmi podielajú na hrách a prechádzkach s det'mi a na starostlivosti o dospelého člena rodiny, a d'alej na starostlivosti o vnúčatá a na vodení detí do materskej školy, školy, či na krúžky. Pri bežnej opatere detí, dozeraní nad školskými povinnostami a pri čerpaní vol'na pri chorobe dietatata je ich účast' podstatne slabšia.

Nedá sa preto hovorit o celkovej zmene úlohy otca. Účast' otcov pri starostlivosti o dietáa je selektívna. Z činností, ktoré sú nutné pre zabezpečenie každodennej starostlivosti o dietáa si vyberajú tie, ktoré podporujú emocionálne obohatenie a vyhovujú ich potrebám a želaniam (šport, výlety, hry). Činnosti, ktoré sú nutné pre fungovanie každodenného života dietatáa, zostávajú nad'alej povinnostou a úlohou matky, na ktorú sa presúva aj celková zodpovednost' za starostlivost́ o dieta a jeho výchovu. Väzba matka - dietáa je stále najstabilnejšou rodinnou väzbou a najstabilnejšou sociálnou väzbou vôbec. Môžeme teda konštatovat', že vo všeobecnosti narastá čas, ktorý otcovia trávia v spoločnej činnosti s det'mi, nevyrovná sa však času, ktorý im venujú mnohokrát zamestnané matky.

\section{MODELY RODIČOVSKÝCH ROLÍ}

Aj napriek zmenám $v$ oblasti rodičovských rolí faktom zostáva, že i zamestnané ženy nad'alej vykonávajú väčšinu domácich prác. Táto skutočnost' je neraz označovaná ako retradicionalizácia alebo pasca zrovnoprávnenia (Ondrejkovič - Majerčíková, In Ondrejkovič et al., 2006, 38). V súvislosti $s$ problematikou rozdelenia úloh $v$ rodine sa nám zdajú výstižné tri modely usporiadania rodičovských rolí, ktoré vymedzila Maříková $(2006,86)$ :

I. Najrozšírenejším modelom je model, ktorý sa dá charakterizovat' ako: „väčšina (miernejšie „vel'a“) je na žene. Pri tomto modeli, aj ked' sa muži pri výchove a starostlivosti o diet́a angažujú, resp. čiastočne angažujú, vystupujú voči žene (matke) v role pomocníka, a nie rovnocenného partnera. Muži sa totiž zapájajú len vtedy, ked' je to potrebné (tzn. vtedy, ked'žena - matka z nejakého dôvodu nemôže, alebo prítomnost' druhého rodiča je nutná), alebo - a to je častejšie - ked' chcú, t. j. oni (muži) majú čas - teda podla svojich časových možností. $V$ tomto modeli plní otec rolu tzv. pomáhajúceho otca, ktorý najčastejšie vystupuje voči svojim detom ako ten, kto sa stará o náplň ich vol'ného času hrá sa s nimi, chodí s nimi von, športuje s nimi, prípadne sa s nimi niekedy i učí. Otec je teda kamarátom detí pre vol'ný čas. Tento typ otcov obvykle zastáva pomerne tradičný názor na rolu matky (podl'a nich starostlivost' o deti je primárne záležitostou matky). 
Uvedený typ otca je akýsi zmiešaný, prechodný typ medzi typom tradičného a typom tzv. nového otca.

II. V časti rodín sa doposial' uplatňuje pomerne konzervatívny model starostlivosti o dieta, ktorý by sa dal charakterizovat: „,v̌̌etko je na žene“. Tá trávi s det́mi najviac času, najviac sa im venuje, lebo zabezpečuje každodennú základnú starostlivost' o ne: komunikuje s nimi face to face, stará sa tiež o náplň ich vol'ného času. Okrem toho na nej spočíva hlavný podiel zodpovednosti za ich výchovu. Matka sa tak ocitá v role najdôležitejšej osoby v živote detí.

Muži - otcovia v tomto rodinnom modeli reprezentujú typ tradičného otca, ktorý však má dva varianty. Prvý typ je známy z doby socializmu, ktorý sa v rodine nemusí príliš angažovat' (svet práce aj vol'ného času je mimo rodinu). Títo otcovia sa obvykle angažujú v špecifických výchovných situáciách, kedy sa snažia zasahovat' mocensky (zakazujú, nariad'ujú, prikazujú, prípadne trestajú).

Druhým variantom je nová verzia starého typu, t. j. „noví tradiční otcovia“, pre ktorých je primárna ich profesia a úspech v nej (lebo podnikajú, zastávajú topmanažérske pozície, vykonávajú vysoko kreatívne povolanie). Títo muži bývajú profesijne vel'mi úspešní a nemajú takmer žiadny vol'ný čas. Svoju časovú zaneprázdnenost' "kompenzujú" rodine formou značne vysokého finančného zabezpečenia, dostatočného finančného zázemia, ktoré umožňuje ženám - matkám nepracovat', alebo pracovat' na čiastočný úväzok, pokial' chcú.

III. Najmenej rozšíreným modelom je partnerský model (alebo tiež model zdielaného rodičovstva), kde podiel rodičov na starostlivosti o dieta a na jeho výchove je relatívne najviac rovnocenný, vyrovnaný. To nemusí nutne znamenat', že obaja robia to isté (aj ked' je to možné), skôr každý z rodičov sa dietáatu venuje podl'a svojich možností a časových dispozícií. V tomto modeli sa objavuje typ "starostlivých otcov". Tí odmietajú tradičný model usporiadania rodičovských rolí, kde muž je živitel'om a matka opatrovatel'kou. Títo muži sú presvedčení o tom, že muž by sa mal aktívne podiel'at' na starostlivosti o deti a na chode domácnosti, a tak aj činia. Niektorí títo otcovia sú na rodičovskej dovolenke, iní vykonávajú takú prácu, resp. povolanie, ktoré im umožňuje venovat' sa i rodine - detom.

Podla názorov sociológov ženy uprednostňujú participatívny model častejšie. Naopak, medzi mužmi je viac zástancov tradičného názoru, že starostlivost' o členov rodiny by mala byt' výhradnou úlohou ženy. Ženy sú silnejšími zástankyňami spravodlivejšej del'by práce v domácej sfére než muži, medzi ktorými sa častejšie vyskytuje názor, že zodpovednost' za domácnost' i starostlivost' o členov rodiny by mala ležat' predovšetkým na ženách. Takéto tradičnejšie predstavy sú častejšie u mužov s nižším vzdelaním, u ludí vykonávajúcich manuálnu prácu a tiež vo vidieckom prostredí (Filadelfiová, In Bútorová et al., 2008, 238).

Podl'a Bútorovej (In tamtiež, 33) príklon k partnerskému modelu del'by práce v rodine je silnejší u žien. Detailnejší pohl'ad odhal'uje, že viac zástancov rovnomernej del'by práce je vo vzdelanejšom prostredí. Patriarchálny model, vyznačujúci sa kumuláciou rozhodovania do rúk „hlavy rodiny“, malou participáciou muža na starostlivosti o deti a domácnost' a autoritatívnou výchovou detí, vyhovuje skôr l'udom vyššieho veku; s nízkym vzdelaním; vykonávajúcim nízkokvalifikovanú prácu, pocit́ujúcim spolunáležitost' $\mathrm{k}$ najnižšej spoločenskej vrstve. Na druhej strane nadštandardnou inklináciou k partnerskému modelu rodiny sa vyznačujú mladšie ženy a muži; s vyšším vzdelaním; l'udia, ktorí sami seba a svoju rodinu zarad'ujú do strednej vrstvy. Najsilnejším faktorom je vzdelanie. Výsledky výskumu ukazujú, že čím je vyššie, tým väčšmi sa ženy a muži hlásia k partnerskému modelu rodiny. Tento rozdiel nepriamo svedči o zotrvačnosti a účinnosti rodovo špecifickej socializácie, ktorá sa uplatňuje $\checkmark$ rozličných prostrediach $-v$ rodinách, $v$ škole, $v$ neformálnej výchove či $v$ médiách. Podla $A$. Dombi (2010) vnútrorodinná del'ba práce ovplyvňuje vývin detskej osobnosti a M. Dombi (2012) zdôrazňuje, že premena materskej roly má významný podiel na tomto vývinovom procese. 


\section{ZÁVER}

Uviedli sme charakteristiky súčasnej postmodernej rodiny, ktoré nám slúžili ako východisko pre analýzu súčasného stavu vnútrorodinnej del'by práce. Na základe analýzy empirických zistení sme sa pokúsili objasnit́ participáciu mužov a žien na každodenných prácach v domácnosti a na starostlivosti o deti.

Namiesto záveru heslovite uvedieme trendy a zistenia $v$ oblasti del'by rodinných povinností medzi otcov a matky na Slovensku, ktoré vyplynuli z empirického výskumu „Úloha mužov pri podpore rodovej rovnosti: Participácia otcov na domácej starostlivosti (názory a skúsenosti populácie SR, 2006), kedže korešpondujú v texte uvedenými zisteniami:

- postupne sa prejavuje rastová tendencia delenej starostlivosti (participatívny model);

- objavuje sa malá skupina rodín, kde starostlivost' zabezpečujú výlučne otcovia;

- stále však platí, že väčší podiel zodpovednosti za starostlivost' o rodinu zostáva na pleciach matiek;

- participatívny model rodinnej starostlivosti sa stal prevažujúcim len v prípade tých činností, ktoré majú charakter vol'nočasových aktivít, u ostatných druhov starostlivosti (každodenné povinnosti) zostáva otec nad'alej iba v menšinovej pozícii;

- porovnanie situácie medzi rodičovskými a súčasnými rodinami ukázalo, že došlo $\mathrm{k}$ poklesu tradičného modelu a modelu dvojitého zataženia žien, ktorý sa prejavil v raste partnerského modelu a netradičných modelov rodiny;

- faktom však zostáva, že aj v súčasných rodinách dominuje taký model rodiny, ktorý je založený na participácii obidvoch rodičov vo svete platenej práce, ale starostlivostou o deti a domácnost́ sú zat'ažené matky;

- partnerský model, napriek tomu, že v porovnaní generácií narástol, sa týka stále iba štvrtiny súčasných dvojrodičovských rodín s det'mi.

Celkovo teda možno konštatovat', že na Slovensku (i v Čechách) prevláda stereotypné rozdelenie prác v domácej sfére na ženské a mužské. Ženy väčšmi preferujú partnerský model a muži väčšmi zastávajú patriarchálny model. Rovnost' $v$ prístupe $\mathrm{k}$ zamestnaniu sa teda iba $v$ malej miere prejavuje vo vnútrorodinnej del'be práce, ktorá zostáva rodovo špecifická. Prevažná väčšina žien a matiek sa dokonca i cíti zodpovedná za vedenie domácnosti a starostlivost' o diet́a. Vzniká tak rozpor: na jednej strane ideál, ba i norma vyrovnaných partnerských vztáahov i v domácnosti, ale faktické pokračovanie $\checkmark$ rodovo špecifickej del'be práce $v$ domácnosti.

Súčasná spoločnost' akceptuje dvojité zataženie ženy s väčším dôrazom na jej materskú rolu. Naopak, len vel'mi pozvol'na sa do praxe presadzuje rovnost' podmienok pre muža a ženu $k$ celodennej starostlivosti o malé diet́a. Pretože zosúladenie a vykonávanie rodinných a pracovných povinností je vždy výsledkom súhry mnohých faktorov, a často sa v nich stretávajú ideálne predstavy s reálnymi možnostami, môžu byt́ často i zdrojom konfliktov a napätia. Je preto dôležité sledovat', ako sú rodinné usporiadania, vrátane rozdelenia domácich prác, subjektívne vnímané a hodnotené.

\section{LITERATÚRA}

Bodnárová, B. et al. (2004). Transformácia sociálneho systému na Slovensku: stav, výsledky, riziká narušenia sociálnej súdržnosti a modely riešenia. Priebežná správa z 2. etapy riešenia úlohy. Bratislava: Stredisko pre štúdium práce a rodiny. 
Bútorová, Z. et al. (2008). Ona a On na Slovensku, zaostrené na rod a vek. Bratislava: Inštitút pre verejné otázky.

Daniels, P. \& Weingarten, K. (1983). Sooner or later: The timing of parenthood in adult lives. New York: Norton.

Dombi, A. (2010). A kisgyermekkori élmények hatása a gyermek fejlődésére. In A. Dombi \& K. Soos (Eds.), Fejezetek a kisgyermeknevelés köréböl (s. 82-83). Gyula: APC stúdió.

Dombi, M. (2012). Az én gyerekem más. A szociálpedagógus szerepe a szülői elfogadás, segítségnyújtás támogatásában problémás gyerekek esetében. In A. Dombi \& M. Dombi (Eds.), Fejezetek a szociálpedagógia köréböl (s. 117-125). Szeged: Universitas Kiadó.

Filadelfiová, J., Kiczková, Z. \& Szapuová, M. (2006). Úloha mužov pri podpore rodovej rovnosti: participácia otcov na domácej starostlivosti (názory a skúsenosti populácie SR). Dostupné z http://www.snslp.sk/images/stories/file/projekty/ulohamuzov/05_empririckyvyskum_skratena-verzia.pdf.

Guráň, P., Filadelfiová, J. \& Ritomský, A. (1997). Tradičné verzus moderné: zmeny a život súčasných rodín. In Sociológia - Slovak Sociological Review, 29 (1), 5-20.

Holubová, B. (2006). Nová maskulinita po slovensky. In Ondrejkovič, P. et al., Rodina v novom miléniu (s. 89-99). Nitra: FSVaZ UKF.

Holubová, B. (2011). Súhrnná správa o stave rodovej rovnosti na Slovensku rok 2010. Bratislava: Inštitút pre výskum práce a rodiny.

Chaloupková, J. (2005). Faktory ovlivňující dělbu domácí práce v českých domácnostech a hodnocení její spravedlnosti. In Sociologický časopis/Czech Sociological Review, (41), 57-77.

Klocoková, J. (2004). Domáce práce z perspektívy symbolických funkcií a sociálnych významov. In Sociológia - Slovak Sociological Review, 36(5), 455-472.

Lewis, M. et al. (1981). The father as a member of the child'social netwoork. In Lamb, M.E. (Ed.), The role of father in child development. New York: John Wiley.

Maříková, H. (1999). Muž v rodině: Demokratizace sféry soukromé. Praha: SÚ AV ČR.

Maříková, H. (2006). Muži mezi rodinou a prací. In Ondrejkovič, P. et al., Rodina v novom miléniu (s. 81-88). Nitra: FSVaZ UKF.

Matějček, Z. (1989). Rodiče a deti. Praha: Avicenum.

Možný, I. (1990). Moderní rodina (mýty a skutečnosti). Brno: Blok.

Možný, I. (2002). Sociologie rodiny. 2. vyd. Praha: Slon.

Možný, I. (2006). Rodina a společnost. Praha: Slon.

Ondrejkovič, P. \& Majerčíková, J. (2006). Zmeny v spoločnosti a zmeny v rodine - kontinuita a zmena, In Sociológia - Slovak Sociological Review, 38 (1), 5-30.

Plaňava, I. (2002). Manželství a rodiny. Brno: Doplněk.

Rabušic, L. (2001). Kde ty všechny děti jsou? Praha: Slon.

Střelec, S. (2007). Rodina jako výchovný činitel. In Střelec, S., Studie z teorie a metodiky výchovy II. (s. 109-124). Brno: MU.

Singly, F. de. (1999). Sociologie současné rodiny. Praha: Portál.

Tamášová, V. (2007). Teória a prax rodinnej edukácie. Ivanka pri Dunaji: AXIMA.

Vajda, Zs. \& Kósa, E. (2005). Neveléslélektan. Budapest: Osiris. 
Výrost, I. \& Slaměník, J. (2001). Aplikovaná sociální psychologie. Praha: Portál.

Yablonsky, L. (1995). Otcové a synové. Praha: Portál.

\title{
Autor
}

PaedDr. Eleonóra Mendelová, PhD., Katedra pedagogiky PF UKF, Dražovská 4, 94901 Nitra, SR, e-mail: emendelova@ukf.sk

\section{The Contemporary Postmodern Family and the Division of Work Inside the Family}

\begin{abstract}
In accordance with changes in social conditions, family life experiences its own development and as a result of it, the traditional family changed into the modern family and then to the postmodern family. The article presents descriptions of the current postmodern family, which form a basis for the analysis of the work division inside the family. The aim of the paper is to present the current state of patrimonial division of work inside the family and to detect the participation of men and women in everyday duties and work in the household and participation in child care, based on the empirical findings (with emphasis on Slovak and Czech research). The next aim is to analyse opinions and expectations of people in the area of parental roles and get an answer to the question, whether equal relationships exist in current families or there is a continuation of specific gender divisions of work in the household.
\end{abstract}

Keywords: postmodern family, division of work, mother, father, house works, child care, parental roles 